\title{
Skema Bisnis Sosial Air Minum Avasya Water Untuk Desa Oesusu, NTT
}

\author{
Maria Sutanto, Adela Putri, Carissa Effendy, Maizkha Sumbada, Wynn Nathaniel
}

School of Business and Economics Universitas Prasetiya Mulya

JL. RA. Kartini (TB Simatupang), Cilandak Barat Jakarta Selatan, Jakarta 12430 Indonesia.

*. Corresponding Author: mariatan93@hotmail.com

\begin{abstract}
Eligible drinking water infrastructure contributes to the quality of human life up to $94 \%$. This research aims to describe and analyze the drinking water access, community behavior in accessing drinking water, drinking water problem in Oesusu Village. The research is qualitative with data collection through interview and observation. The results show that the distribution of drinking water infrastructure solutions in Oesusu village is currently uneven and the water treatment process has not able to produce adequate drinking water. Therefore, Avasya water established a sustainable business ecosystem to provide one-stop drinking water solutions for Oesusu village community.
\end{abstract}

\footnotetext{
Abstrak

Infrastruktur air minum yang layak berkontribusi terhadap kualitas kehidupan manusia hingga 94\%. Penelitian ini bertujuan untuk mendeskripsikan dan menganalisis akses air minum, perilaku masyarakat dalam mengkonsumsi air minum dan masalah air minum yang dihadapi di Desa Oesusu. Penelitian menggunakan jenis kualitatif dengan teknik pengumpulan data melalui wawancara dan observasi. Hasil penelitian menunjukkan bahwa implementasi solusi infrastruktur air minum di desa Oesusu saat ini belum merata dan proses pengolahan air minum oleh masyarakat belum dapat menghasilkan air minum yang layak. Sehingga dari masalah ini, Avasya water membentuk sustainable business ecosystem untuk memberikan one-stop solutions untuk masyarakat desa Oesusu.
}

\section{ARTICLE INFO}

Keywords - Drinking Water Infrastructure, Drinking Water Access, Oesusu Village, Sustainable Business Ecosystem

Kata Kunci -- Infrastruktur Air Minum, Akses Air Minum, Desa Oesusu, Sustainable Business Ecosystem 


\section{PENDAHULUAN}

Air merupakan kebutuhan dan hak dasar manusia yang sudah selayaknya diterima masyarakat. Sementara itu, hingga saat ini jutaan orang di Indonesia masih kekurangan air minum dan sebagai dampaknya, banyak masyarakat di Indonesia menderita berbagai masalah kesehatan. Pada 2017, sebanyak 62,10\% wilayah Indonesia masih kurang terlayani dalam mendapatkan akses air minum yang aman untuk dikonsumsi (BPS 2017).

Lebih dari 45 juta orang di Indonesia tidak mendapatkan akses air layak minum karena memiliki keterbatasan infrastruktur. Ketersediaan infrastruktur air di daerah tertinggal di Indonesia hanya terbatas pada sumber air dari sumur gali, sungai, dan air hujan. Namun, sumber air ini seringkali tidak memadai selama musim kemarau dan berdampak buruk pada kesehatan, seperti diare, terutama bagi bayi dan balita yang rentan untuk terjangkiti atau meninggal akibat diare. Sanitasi dan air minum yang layak berkontribusi langsung pada kualitas kehidupan manusia dengan mengurangi risiko diare hingga 94\% (Kementerian Kesehatan 2015). Berdasarkan data statistik dari Survei Demografi dan Kesehatan Indonesia tahun 2007, 13,7\% balita menderita dan meninggal akibat diare. Sekitar $31,4 \%$ bayi dan $25,2 \%$ balita yang terinfeksi oleh diare meninggal pada 2007 (Buletin Jendela 2011). Angka kematian diare di Provinsi NTT merupakan salah satu yang tertinggi di antara provinsi lainnya di Indonesia sebesar 3.04\%, dimana angka ini jauh dari ekspektasi target angka kematian yang ditetapkan oleh Kementrian $\begin{array}{llll}\text { Kesehatan } & \text { RI } & \text { yaitu } & \text { sebesar }\end{array}$

Kecamatan Takari, Kabupaten Kupang, NTT merupakan salah satu wilayah yang memiliki keterbatasan akses air minum yang dipengaruhi oleh sulitnya akses air bersih. Karena kesulitan air dan keterbatasan infrastruktur, penduduk desa harus mengkonsumsi air minum yang tidak aman. Sebagai implikasinya, pada tahun 2015 ada 461 kasus diare di Kecamatan Takari tepatnya di Oesusu dan desa-desa sekitarnya yang mempengaruhi produktivitas masyarakat setempat.

Melihat permasalahan mengenai akses air minum di atas, penulis akan mendeskripsikan dan menganalisis akses air minum, perilaku masyarakat dalam mengkonsumsi air minum dan masalah air minum yang dihadapi di Desa Oesusu. Selain itu, penulis juga akan memberikan solusi skema bisnis sosial Avasya Water untuk menyelesaikan permasalahan tersebut. 


\section{TINJAUAN PUSTAKA}

Berdasarkan tinjauan dari Peraturan Menteri Kesehatan Republik Indonesia nomor 492 tentang Persyaratan Kualitas Air Minum, air minum adalah air yang melalui proses pengolahan atau tanpa proses pengolahan yang memenuhi syarat kesehatan dan dapat langsung diminum. Untuk menjustifikasi air minum tersebut aman bagi kesehatan, maka Menteri Kesehatan sudah menetapkan beberapa parameter wajib dan parameter tambahan yang disebutkan dalam lampiran peraturan tersebut. Parameter-parameter ini meliputi persyaratan fisika, mikrobiologis, kimiawi dan radioaktif.

Air baku untuk keperluan air minum sudah ditetapkan oleh Peraturan Menteri Pekerjaan Umum dan Perumahan Rakyat Republik Indonesia nomor 19 tentang Pemberian Dukungan oleh Pemerintah Pusat dan/atau Pemerintah Daerah dalam Kerjasama Penyelenggaraan Sistem Penyediaan Air Minum. Di dalam peraturan ini, disebutkan bahwa air baku merupakan air yang berasal dari sumber air permukaan, air tanah, air hujan dan air laut yang memenuhi baku mutu tertentu sebagai air baku untuk air minum.

Pengertian dari istilah sumber air ini dijelaskan lebih lanjut sebagai berikut.

1. Air permukaan adalah air hujan yang mengalir di permukaan bumi. Dalam proses pengalirannya, air permukaan sering tercemari oleh batang-batang kayu, daun-daun, zat organik dan sebagainya (Sutrisno \& Suciastuti 2006).

2. Air tanah adalah air hujan atau air permukaan yang meresap ke dalam tanah melalui poripori tanah yang ada pada lapisan tanah. Lapisan tanah ini berfungsi sebagai saringan, sehingga semakin dalam air meresap melalui lapisan-lapisan ini, maka semakin baik kualitas air yang didapatkan. Air tanah yang keluar dengan sendirinya dari dalam tanah menuju permukaan disebut dengan mata air, yang mana kualitasnya sama dengan air tanah yang telah meresap dalam (Sutrisno \& Suciastuti 2006).

3. Air laut memiliki sifat asin karena air ini mengandung garam, atau dalam bahasa kimianya disebut dengan $\mathrm{NaCl}$ (Sutrisno \& Suciastuti 2006).

4. Air hujan adalah uap air yang sudah mengalami kondensasi (perubahan uap air menjadi tetes air yang sangat kecil), kemudian jatuh ke bumi berbentuk air. Pada waktu terbentuk 
uap air terjadi proses transformasi (pengangkutan uap air oleh angin menuju daerah tertentu yang akan terjadi hujan). Menurut Waluyo (2005) dan Lee at al. (2010), ketika proses transformasi tersebut uap air tercampur dan melarutkan gas-gas oksigen $(\mathrm{O} 2)$, nitrogen $(\mathrm{N})$, karbondioksida $(\mathrm{CO} 2)$, debu, dan senyawa lain. Karena itulah air hujan juga mengandung debu, bakteri, serta berbagai senyawa yang terdapat dalam udara, sehingga kualitas air hujan juga banyak dipengaruhi oleh keadaan lingkungannya (Hamonangan 2011).

\section{METODE PENELITIAN}

Penelitian ini menggunakan jenis penelitian kualitatif. Objek penelitian ini adalah akses air minum, perilaku masyarakat dalam mengkonsumsi air minum dan masalah air minum yang dihadapi di Desa Oesusu. Subjek penelitian masyarakat di desa Oesusu, Kecamatan Takari, Kabupaten Kupang; Kepala Desa Oesusu ; Lembaga Swadaya Masyarakat; tenaga ahli teknologi water treatment; pelaku perusahaan yang melakukan Corporate Social Responsibility ; serta supplier teknologi water treatment. Jenis data yang digunakan adalah data kualitatif. Sumber data yang digunakan adalah sumber data primer. Metode pengumpulan data adalah melalui wawancara semi struktur dan observasi non partisipatif. Teknik penentuan informan adalah informan yang telah lama dan intensif menyatu dengan aktivitas pengkonsumsian air minum dan terikat secara penuh serta tinggal di desa yang diteliti (Spradley dalam Faisal 1990). Teknik pengujian keabsahan data adalah menggunakan teknik member check dari peneliti kepada pemberi

data.

\section{BAB IV: ANALISIS DATA}

\section{Profil Daerah}

Desa Oesusu merupakan sebuah desa yang terletak di Kecamatan Takari, Kabupaten Kupang, Provinsi Nusa Tenggara Timur. Desa Oesusu memiliki 6 dusun dengan jumlah kepala keluarga (KK) sebagai berikut.

Tabel 4.1. Jumlah KK per Dusun di Desa Oesusu 


\begin{tabular}{|c|c|c|}
\hline Dusun No. & Nama Dusun & Jumlah KK \\
\hline & Dusun Komlol & 81 \\
\hline 2. & Dusun Talaka 2 & 64 \\
\hline 3. & Dusun Talaka 3 & 65 \\
\hline 4. & Dusun Oesusu Dalam & 53 \\
\hline 5. & Dusun Oelnunu & 49 \\
\hline 6. & Dusun Kiukenat & 38 \\
\hline
\end{tabular}

\section{$\underline{\text { Akses Air Minum di Desa Oesusu }}$}

Ketersediaan akses air minum berpengaruh erat dengan adanya ketersediaan akses atau sarana air bersih. Menurut Data BPS tahun 2017 dalam laporan kecamatan Takari dalam angka menyebutkan bahwa dari 10 sarana air bersih yang tersedia di Desa Oesusu, hanya sekitar 5 sarana saja yang memenuhi syarat sebagai solusi untuk penyediaan air bersih (BPS 2017). Untuk memvalidasi hal tersebut, dalam studi lapangan kami melakukan observasi langsung dan wawancara kepada penduduk dan pemerintah desa terkait fasilitas air yang menjadi solusi saat ini. Aspek yang dinilai adalah kondisi fasilitas air bersih, jarak perumahan penduduk dengan fasilitas air bersih, penyebaran fasilitas air bersih, dan kualitas air yang tersedia.

Secara umum, keadaan fasilitas air di desa Oesusu menurut hasil observasi dan wawancara adalah dalam keadaan baik. Hal ini terbukti dari kelancaran distribusi air ke rumahrumah warga. Sistem Penyedia Air Minum (SPAM) yang diterapkan untuk fasilitas air minum adalah tersentralisasi melalui satu sumber air yang sejak tahun 2014 mulai dikelola oleh Pemerintah Desa, tepatnya di bawah naungan Badan Usaha Milik Desa. Sejak pengelolaan diambil alih dari PDAM oleh BUMDES, baik masyarakat maupun pemerintah desa mengakui bahwa kondisi fasilitas air lebih terkelola dengan baik dan transparan.

Berdasarkan hasil wawancara dengan kepala desa Oesusu, secara karakteristik demografi, terdapat dua area di Desa Oesusu, yaitu dusun atas dan dusun bawah. Yang termasuk dalam dusun atas adalah Dusun Oesusu Dalam dan Dusun Oelnunu, sementara yang termasuk dalam dusun bawah adalah Dusun Komlol, Dusun Talaka 2, Dusun Talaka 3, dan Dusun Kiukenat. Perbedaan karakteristik ini mempengaruhi akses air layak minum di desa Oesusu, terutama dari segi jarak dan persebaran fasilitas air. 
Jarak fasilitas penampungan air yang tersentralisasi ke perumahan penduduk cukup jauh. Oleh karena itu, air dari tempat tersebut dialirkan menggunakan pipa ke rumah-rumah warga memanfaatkan hukum gravitasi. Infrastruktur ini disediakan oleh Dirjen Cipta Karya pada tahun 2014 dengan jumlah investasi sebesar 7.8 miliar dan debit/ menit adalah 15 L. Adanya infrastruktur SPAM ini mempermudah akses air bagi masyarakat di dusun bawah karena warga bisa mendapatkan air langsung melalui keran di halaman rumahnya masing-masing. Warga dusun bawah diharuskan membayar iuran sebesar Rp 25,000 dengan penggunaan air minimum $25 \mathrm{~m}^{3}$ setiap bulannya.

Sementara itu untuk penduduk di dusun atas masih harus berjalan ke sumber air terdekat berjarak lebih kurang $3 \mathrm{~km}$ untuk mengambil sendiri air menggunakan wadah penampung dan membawanya ke rumah. SPAM tidak mencapai dusun atas karena tidak adanya pompa yang dapat mendorong air ke dusun yang memiliki ketinggian di atas mata air Oesusu. Di dusun atas, hanya terdapat infrastruktur yang disediakan oleh program Penyediaan Air Minum dan Sanitasi Berbasis Masyarakat (PAMSIMAS). Infrastruktur ini mengambil air dari mata air Oesusu untuk dialirkan ke beberapa titik di dusun 4. Menurut LSM setempat, untuk mendapatkan air tanah di tempat ini, dapat dilakukan pengeboran, namun hal ini tidak banyak dilakukan karena struktur tanah yang cukup keras sehingga membutuhkan biaya investasi yang tinggi. Terdapat beberapa perusahaan yang bekerjasama dengan LSM untuk membangun fasilitas air minum yang dibangun dan dihibahkan kepada penduduk setempat. Namun masyarakat mengeluhkan bahwa fasilitas tersebut tidak memberikan dampak yang signifikan karena tidak ada pengelolaan yang baik. LSM setempat menyebutkan bahwa skema hibah yang dijalankan belum bisa menjawab permasalahan karena tidak pihak yang bertanggung jawab untuk mengelola dan memelihara. Hal ini menunjukkan bahwa persebaran pembangunan infrastruktur air masih belum merata antara desa atas dengan desa bawah.

Dari hasil observasi ditemukan juga bahwa air yang diperoleh masyarakat Desa Oesusu mengandung zat kapur, mulai dari partikel besar hingga partikel yang sangat kecil (Gambar 4.1). Hal ini menunjukkan bahwa pada dasarnya kualitas air di Desa Oesusu terkontaminasi oleh banyak partikel sehingga tidak layak untuk diminum. Selain itu berdasarkan hasil observasi keseharian penduduk dan wawancara, secara kuantitas debit air yang tersedia sudah mencukupi kebutuhan masyarakat setempat meskipun mengalami fluktuasi pada saat pergantian musim. 


\section{개다}

Vol.01, No. 2, 2018

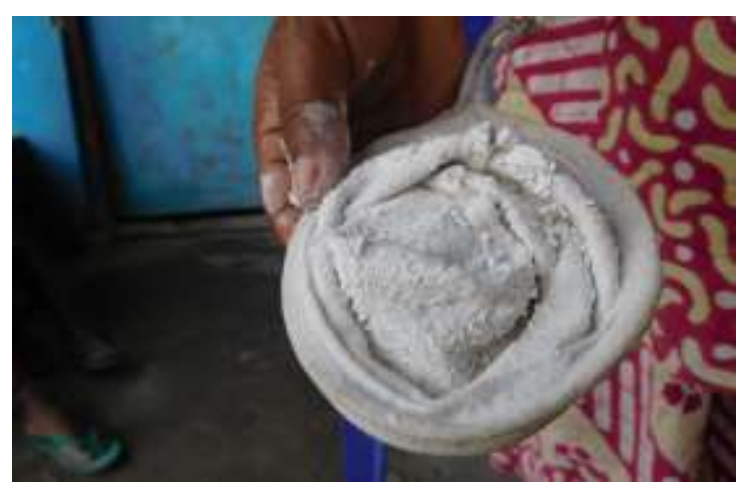

Gambar 4.1. Kondisi air di Desa Oesusu

\section{Perilaku Masyarakat dalam Mengakses Air Minum}

Dalam kesehariannya, kami mengamati masyarakat Desa Oesusu di dusun bawah terbiasa untuk memasak dan menyaring air. Hal ini menunjukkan bahwa penduduk sudah menyadari bahwa air tersebut belum layak untuk diminum dan dampak kesehatan dari konsumsi air yang belum layak untuk diminum. Mereka memasak dan menyaring setidaknya tiga sampai empat kali agar kandungan zat kapur di dalam air dapat berkurang. Proses memasak dan penyaringan ini dilakukan secara masing-masing per rumah tangga yang mana dapat memakan waktu selama lima jam. Meskipun telah dilakukan proses pemasakan air dan penyaringan zat kapur yang mengendap, kandungan zat kapur pada air tetap tidak hilang seluruhnya sehingga tetap berpotensi memberikan dampak buruk terhadap kesehatan saat diminum. Namun, penduduk yang telah menyadari dampak buruk dari kualitas air yang mereka minum ini masih mempercayai bahwa air yang telah mereka proses sudah layak untuk diminum.

Untuk kebutuhan memasak, warga Desa Oesusu masih memakai metode konvensional dengan menggunakan tungku dan kayu api. Dari hasil wawancara, sebagian besar dari warga mengambil kayu api hampir setiap hari dan mereka harus berjalan lebih dari $3 \mathrm{~km}$ untuk mengambil kayu api tersebut. Tentunya, kebutuhan akan kayu api tergantung dari seberapa sering mereka perlu untuk memasak.

Dalam wawancara, penduduk juga menjelaskan alasan mereka mengolah air tersebut selain karena menyadari kontaminasi kapur, yaitu mereka tidak ingin membeli AMDK secara rutin. Meskipun warga harus bersusah-payah mencari kayu bakar dan menyaring air setiap hari, mereka cenderung untuk lebih memilih metode ini karena faktor rasa air, kepercayaan pada 
produk yang tidak diolah sendiri, dan harga. Bagi mereka, AMDK hanya dibeli untuk keperluan pesta. Seorang warga juga menyebutkan bahwa AMDK tergolong mahal untuk dikonsumsi sehari-hari. Batas toleransi harga untuk air minum per galon bagi rata-rata penduduk Desa Oesusu adalah Rp. 1,000- Rp.2,000, dimana harga ini jauh lebih murah dari harga jual AMDK di daerah tersebut.

Berbeda dengan dusun bawah yang seluruhnya sudah mendapatkan akses air dengan mudah, sebagian warga dusun Oesusu Dalam dan seluruh warga dusun Oelnunu sulit mendapatkan akses air, sehingga mempengaruhi cara mereka mengkonsumsi air. Akses air semakin dipersulit dengan keterbatasan listrik di kedua dusun ini yang menyebabkan tidak ada lampu sehingga saat malam hari warga mengambil air dengan kondisi gelap gulita. Sulitnya akses air di kedua dusun ini menjadi alasan warga dusun untuk tidak mau melakukan proses lebih lanjut dalam mengkonsumsi air. Selain itu kedua warga dusun ini percaya bahwa meskipun air tersebut tinggi akan kandungan zat kapur, hal ini tidak mempengaruhi kesehatan mereka. Mereka menyebut warga dusun memiliki "ginjal benton" sebagai bentuk ekspresi bahwa kesehatan warga dusun ini tidak dipengaruhi oleh air minum yang tidak diproses.

Untuk penampungan air minum, warga Dusun Atas dan Dusun Bawah menggunakan ember untuk menampung air minum yang sudah di proses. Dimana apabila dilihat secara langsung penampungan dengan ember masih belum dinilai higienis. Hal ini dikarenakan tempat untuk menampung air minum tidak tertutup rapat sehingga beberapa substansi dapat masuk ke ember tersebut.

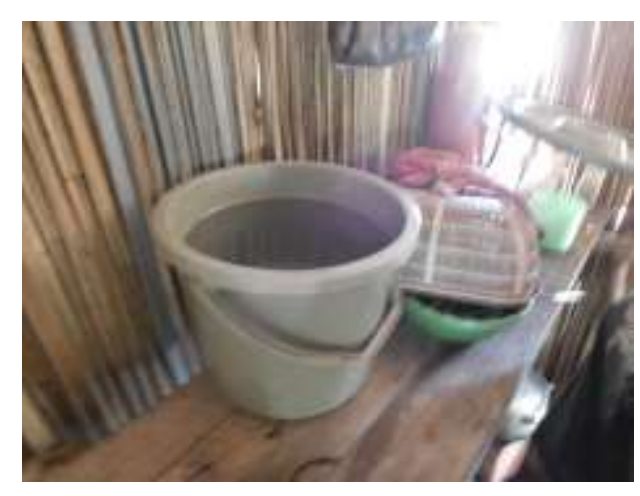

Gambar 4.2 Ember yang digunakan untuk menampung air minum 
Kami juga mengamati kebiasaan beberapa penduduk untuk menampung air dalam jerigen. Ketentuan dari Pemerintah Desa agar setiap rumah tangga mencapai penggunaan air sebanyak minimal $25 \mathrm{~m}^{3}$ per bulannya menyebabkan mereka menampung air dari pipa dalam drum air di lahan masing-masing. Dari hasil observasi, air yang ditampung di dalam drum tidak ditutup sehingga menyebabkan air mudah terkontaminasi terutama oleh nyamuk dan debu.

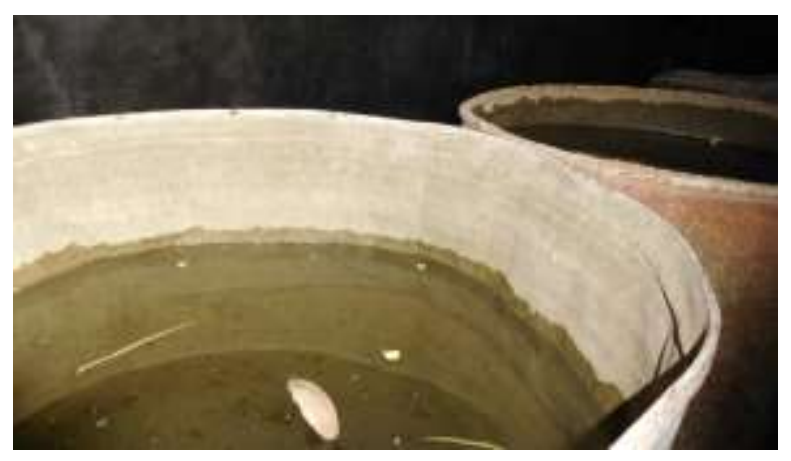

Gambar 4.3. Penampungan Air di Drum Terbuka

\section{Analisa Masalah yang Dihadapi}

Berdasarkan kondisi yang ada di lapangan, dapat dilihat bahwa fasilitas masih belum memadai untuk melayani seluruh desa dan belum bisa menyediakan air yang layak konsumsi karena terkontaminasi. Hal tersebut berdampak pada perilaku masyarakat yang beragam, yaitu melalui usaha mengolah air menjadi air layak minum sampai langsung meminum tanpa mengolah karena kesulitan dalam mengakses fasilitas terdekat.

Menurut salah satu anggota LSM setempat dan seorang pakar CSR, berbagai usaha yang dilakukan masih belum membuahkan hasil karena metode pengolahan yang dilakukan masyarakat saat ini belum cukup signifikan untuk menghasilkan air yang layak minum, bantuan yang diberikan melalui program hibah tidak sesuai dengan kebutuhan masyarakat, dan tidak ada pengelolaan dan pemeliharaan yang baik untuk fasilitas yang dihibahkan. Selain karena tidak adanya pengelolaan yang baik, tidak adanya keterlibatan komunitas masyarakat dalam pembangunan menyebabkan tidak adanya rasa memiliki dari masyarakat terhadap fasilitas yang ada. Sejauh ini LSM setempat sudah mencoba memberikan edukasi bagi masyarakat yang belum mengolah air yang mereka konsumsi, akan tetapi dibutuhkan usaha lebih dan banyak tenaga ahli 
untuk mengedukasi penduduk untuk mengubah kebiasaan lama menjadi pola hidup yang lebih sehat.

\section{Solusi yang Avasya Tawarkan}

Untuk memecahkan masalah yang tepat sasaran Avasya Water memberikan solusi yang menjawab permasalahan desa, yaitu dengan:

\section{Layanan yang menjamin keamanan konsumsi}

Untuk memberikan layanan yang menjamin kesehatan konsumsi, Avasya menggunakan teknologi water treatment dan pengemasan air. Dalam menentukan teknologi yang paling tepat dalam menjawab permasalahan yang terjadi di Desa Oesusu, kami mewawancara Pak I Gede Wenten sebagai pakar di bidang teknologi air. Terdapat dua alternatif teknologi pengambilan sumber air yang dapat digunakan untuk desa tersebut, yaitu alternatif rain water harvesting yang diintegrasikan dengan sistem water treatment dan alternatif river water reservoirs yang diintegrasikan dengan sistem water treatment. Dari kedua teknologi itu, sistem river water reservoirs merupakan metode yang paling tepat untuk diimplementasikan. Teknologi water treatment yang diintegrasikan dalam fasilitas berupa kombinasi dari reverse osmosis dan membran. Selain itu layanan pengemasan dan pengiriman langsung mencegah kontaminasi air dari kontaminan luar.

\section{Skema ekosistem bisnis yang menjamin keberlangsungan layanan}

Skema kerjasama operasional dan distribusi dengan Komite Air desa serta kerjasama program CSR dari segi pendanaan dengan perusahaan investor menjamin keberlangsungan layanan air minum. Melalui skema ini, masyarakat bisa mendapatkan air minum dengan harga terjangkau, fasilitas mendapatkan perawatan rutin, operasional dapat berjalan secara berkelanjutan, serta Komite Air bisa mendapatkan pendapatan tambahan melalui profit sharing yang dapat digunakan untuk investasi ke fasilitas infrastruktur air lainnya yang dapat meningkatkan kesejahteraan masyarakat desa.

Keberlangsungan juga tergantung dari ketepatan fasilitas terhadap kebutuhan masyarakat, oleh karena itu kegiatan studi lapangan dilakukan bersama dengan LSM yang sudah menjalin hubungan dekat dengan masyarakat. 
3. Kolaborasi dengan stakeholder-stakeholder untuk melakukan edukasi yang tepat sasaran

Melalui program community development dan menjamin meningkatnya pengetahuan serta keterlibatan masyarakat dalam mengadopsi pola hidup berkualitas. Kerjasama ini diutamakan pada LSM setempat yang sudah menjalin kedekatan emosional dengan masyarakat setempat. Avasya membantu LSM untuk menghubungkan dengan program atau sumber daya yang tepat dan memiliki ekspertis untuk melakukan edukasi yang terkait. Keterlibatan masyarakat digali melalui program community engagement dan customer relation.

\section{BAB V: KESIMPULAN}

\section{Masalah yang dihadapi}

Berdasarkan penjabaran dari sub-bab di atas, dapat dilihat upaya yang ada hingga saat ini adalah tersedianya proyek-proyek hibah dari perusahaan melalui bantuan LSM setempat, proses pengolahan air secara sederhana menggunakan saringan dan merebus air, serta program edukasi yang difasilitasi oleh LSM. Namun, upaya ini masih belum berhasil untuk menyelesaikan permasalahan di desa karena:

1. Metode yang diterapkan masyarakat belum bisa menghasilkan air yang layak untuk diminum

Hal ini disebabkan oleh kualitas saringan yang digunakan masyarakat belum dapat memisahkan air dari kapur secara sempurna, masih adanya kontaminasi abu dari kayu bakar saat memasak air, dan tidak terstandarisasinya metode serta output air yang diminum oleh masyarakat setempat.

2. Pembangunan fasilitas dari program hibah tidak merata, tidak sustainable, dan tidak tepat guna

Pembangunan yang tidak merata terhambat oleh biaya investasi yang tinggi. Selain itu, keberlangsungan fasilitas juga tidak terjamin karena kurangnya kemampuan operasional dan pemeliharaan alat oleh masyarakat setempat, sehingga fasilitas yang terbangun sering terbengkalai. Ketepatan pembangunan fasilitas yang sesuai dengan kebutuhan masyarakat sangat tergantung dari kualitas riset lapangan, sehingga kualitas riset yang belum benar- 
benar dapat merepresentasikan kebutuhan masyarakat daerah menghambat ketepatan penyediaan fasilitas air minum.

3. Kualitas dan kuantitas edukasi masyarakat terhambat karena kurangnya sumber daya yang ahli secara teknis untuk melakukan edukasi tertentu.

\section{Solusi yang Avasya Tawarkan}

Untuk memecahkan masalah yang tepat sasaran Avasya Water memberikan solusi yang menjawab permasalahan desa, yaitu dengan:

1. Penyediaan teknologi dan layanan yang menjamin keamanan konsumsi

Teknologi yang diintegrasikan dalam fasilitas berupa kombinasi dari reverse osmosis dan membran. Selain itu layanan pengemasan dan pengiriman langsung mencegah kontaminasi air dari kontaminan luar.

2. Skema ekosistem bisnis yang menjamin keberlangsungan layanan

Skema kerjasama operasional dan distribusi dengan Komite Air desa serta kerjasama program CSR dari segi pendanaan dengan perusahaan investor menjamin keberlangsungan layanan air minum. Melalui skema ini, masyarakat bisa mendapatkan air minum dengan harga terjangkau, fasilitas mendapatkan perawatan rutin, operasional dapat berjalan secara berkelanjutan, serta Komite Air bisa mendapatkan pendapatan tambahan melalui profit sharing yang dapat digunakan untuk investasi ke fasilitas infrastruktur air lainnya yang dapat meningkatkan kesejahteraan masyarakat desa.

3. Kolaborasi dengan stakeholder-stakeholder untuk melakukan edukasi yang tepat sasaran melalui program community development dan menjamin meningkatnya pengetahuan serta keterlibatan masyarakat dalam mengadopsi pola hidup berkualitas. 


\section{BAB VI: DAFTAR PUSTAKA}

Badan Pusat Statistik Kabupaten Kupang. (2017). Kecamatan Takari dalam Angka 2017. Takari.

Badan Pusat Statistik. (2016). Persentase Rumah Tangga menurut Provinsi, Tipe Daerah dan Sumber Air Minum Layak tahun 2009-2016. Retrieved from https://www.bps.go.id/linkTabelStatis/view/id/1548

Dwijosaputro. 1981. Dasar - Dasar Mikrobiologi. Jakarta : Djambatan.

Gabriel, J. F. 2001. Fisika Lingkungan. Jakarta: Penerbit Hiprokrates.

Hamonangan, Tumpal. 2011. Analisis Pemanenan Hujan Dari Atap Bangunan (Studi Kasus : Gedung - Gedung Di Kampus IPB Dramaga Bogor) Bogor. http://repository.ipb.ac.id/handle/123456789/47555.

Helmreich B \& Horn H. 2009. Opportunities in rainwater harvesting. Desalination. Vol. 248:18-124.

Istilah/Pengertian. Kementerian Pekerjaan Umum dan Perumahan Rakyat Direktorat Jenderal Cipta Karya. http://ciptakarya.pu.go.id/pam/Istilah/Istilah.htm 
Kodoatie, R.J, dan Roestam Sjarief, Ph.D, 2008, Pengelolaan Sumber Daya Air Terpadu, Edisi Revisi, Yogyakarta : Penerbit Andi.

Kusnaedi. 1995. Mengolah air gambut dan air kotor untuk air minum. Penebar Swadaya. Jakarta

Lee JY, Yang JS, Han M, \& Choi J. 2010. Comparison of the microbiological and chemical characterization of harvested rainwater and reservoir water as alternative water resources. Science of the Total Environment. Vol 408:896-905.

Peraturan Menteri Kesehatan Republik Indonesia Nomor 492/Menkes/Per/IV/2010 tentang Persyaratan Kualitas Air Minum, Menteri Kesehatan Republik Indonesia, Jakarta, 2010.

Peraturan Menteri Pekerjaan Umum dan Perumahan Rakyat Republik Indonesia Nomor 19/PRT/M/2016 tentang Pemberian Dukungan oleh Pemerintah Pusat dan/atau Pemerintah Daerah dalam Kerjasama Penyelenggaraan Sistem Penyediaan Air Minum, Menteri Pekerjaan Umum dan Perumahan Rakyat Republik Indonesia, Jakarta, 2016.

Sutrisno, C.T, dan Suciastuti, Eni. 2006. Teknologi Penyediaan Air Bersih. Jakarta. PT. Rineka Cipta. Cetakan Keenam.

UNEP International Technology Centre. 2001. Rainwater Harvesting. Murdoch University of Western Australia

Waluyo, Lud. 2005. Mikrobiologi Umum. Malang: Universitas Muhammadiyah Malang Prees.

Widianto T, Trisni A. 2008, Penggunaan Teknologi Membran Pada Pengolahan Air Limbah Industri Kelapa Sawit, Workshop Teknologi Industri Kimia dan Kemasan 46-47. 


\section{LAMPIRAN}

Observasi Penelitian

\begin{tabular}{|c|c|c|c|c|}
\hline No & Aspek yang Diamati & Deskripsi & $\mathbf{Y a}$ & Tidak \\
\hline \multirow[t]{5}{*}{1.} & \multirow[t]{5}{*}{ Akses Air Bersih } & Jarak terhadap fasilitas air bersih jauh & & $\checkmark$ \\
\hline & & Kondisi fasilitas air bersih sudah rusak & & $\checkmark$ \\
\hline & & Penyebaran fasilitas tidak merata & $\checkmark$ & \\
\hline & & Kualitas air yang tersedia tercemar & $\checkmark$ & \\
\hline & & $\begin{array}{l}\text { Ketersediaan air bersih cukup untuk memenuhi } \\
\text { kebutuhan masyarakat desa }\end{array}$ & & $\checkmark$ \\
\hline \multirow[t]{4}{*}{2.} & \multirow[t]{4}{*}{$\begin{array}{l}\text { Perilaku Masyarakat dalam } \\
\text { Mengkonsumsi Air Minum }\end{array}$} & Masyarakat memasak air untuk diminum & $\checkmark$ & \\
\hline & & Masyarakat menyaring air untuk diminum & $\checkmark$ & \\
\hline & & $\begin{array}{l}\text { Masyarakat menggunakan wadah yang aman bagi } \\
\text { kesehatan untuk air minum }\end{array}$ & & $\checkmark$ \\
\hline & & $\begin{array}{l}\text { Masyarakat menggunakan wadah penampungan } \\
\text { dengan cara dan wadah yang sesuai standar keamanan }\end{array}$ & & $\checkmark$ \\
\hline
\end{tabular}

\section{TRANSKRIP WAWANCARA}

Berikut adalah keterangan dari transkrip wawancara yang dipaparkan setelah ini.

P : Pewawancara

I-\# : Informan-(nomor informan)

\section{Wawancara 1: Warga Desa Oesusu}

Tanggal Wawancara : 20 September 2017

Tempat / Waktu : : Rumah Warga Desa Oesusu / 13.00 - 17.30 
Jenis Informan $\quad$ : Informan merupakan perwakilan dari 5 sampai 7 orang yang ada di rumah yang sama.

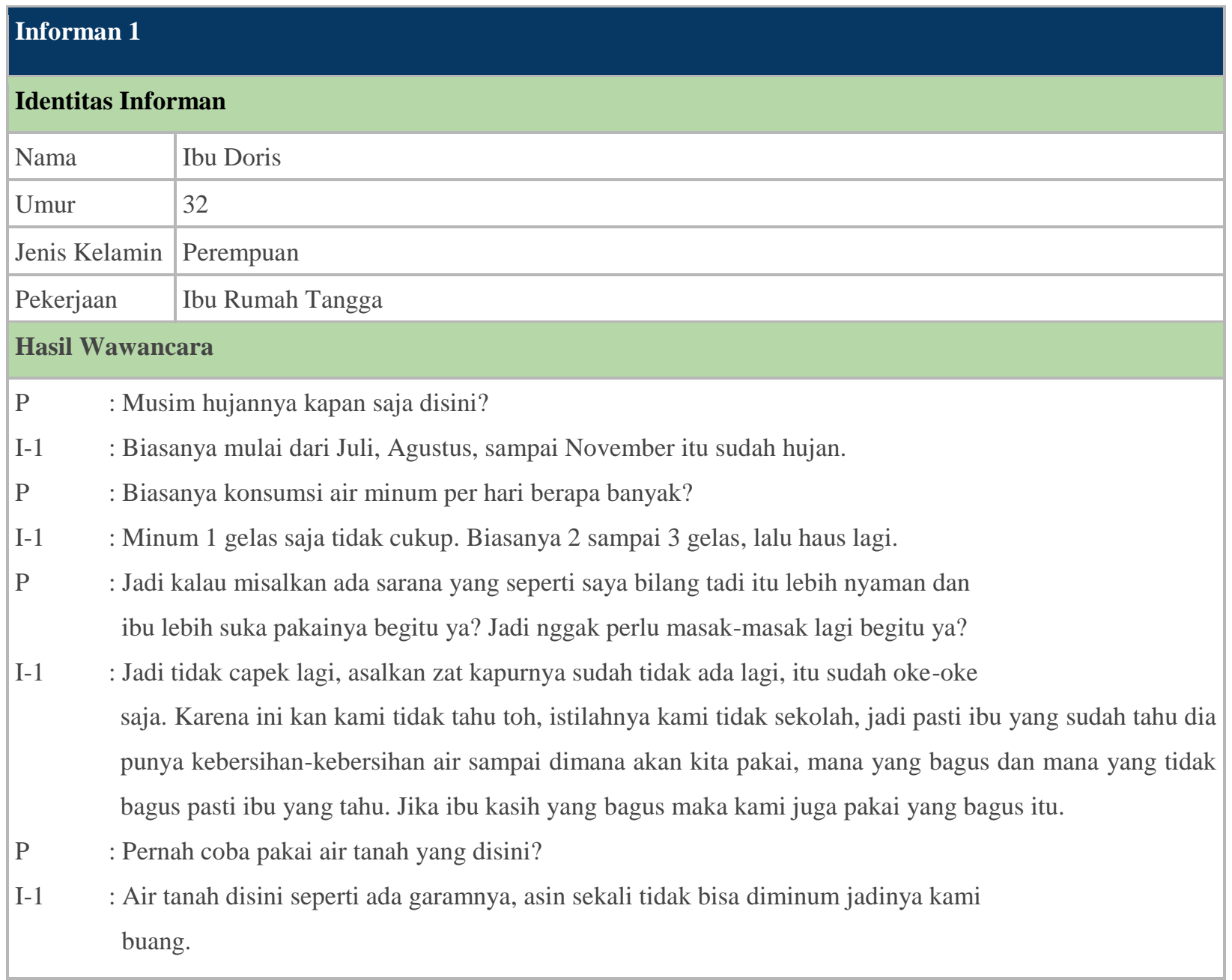

\section{Informan 2}

\section{Identitas Informan}

\begin{tabular}{|l|l|}
\hline Nama & Ibu Elisabeth \\
\hline Umur & 30 \\
\hline Jenis Kelamin & Perempuan \\
\hline Pekerjaan & Ibu Rumah Tangga \\
\hline \multicolumn{2}{l}{ Hasil Wawancara } \\
\hline
\end{tabular}




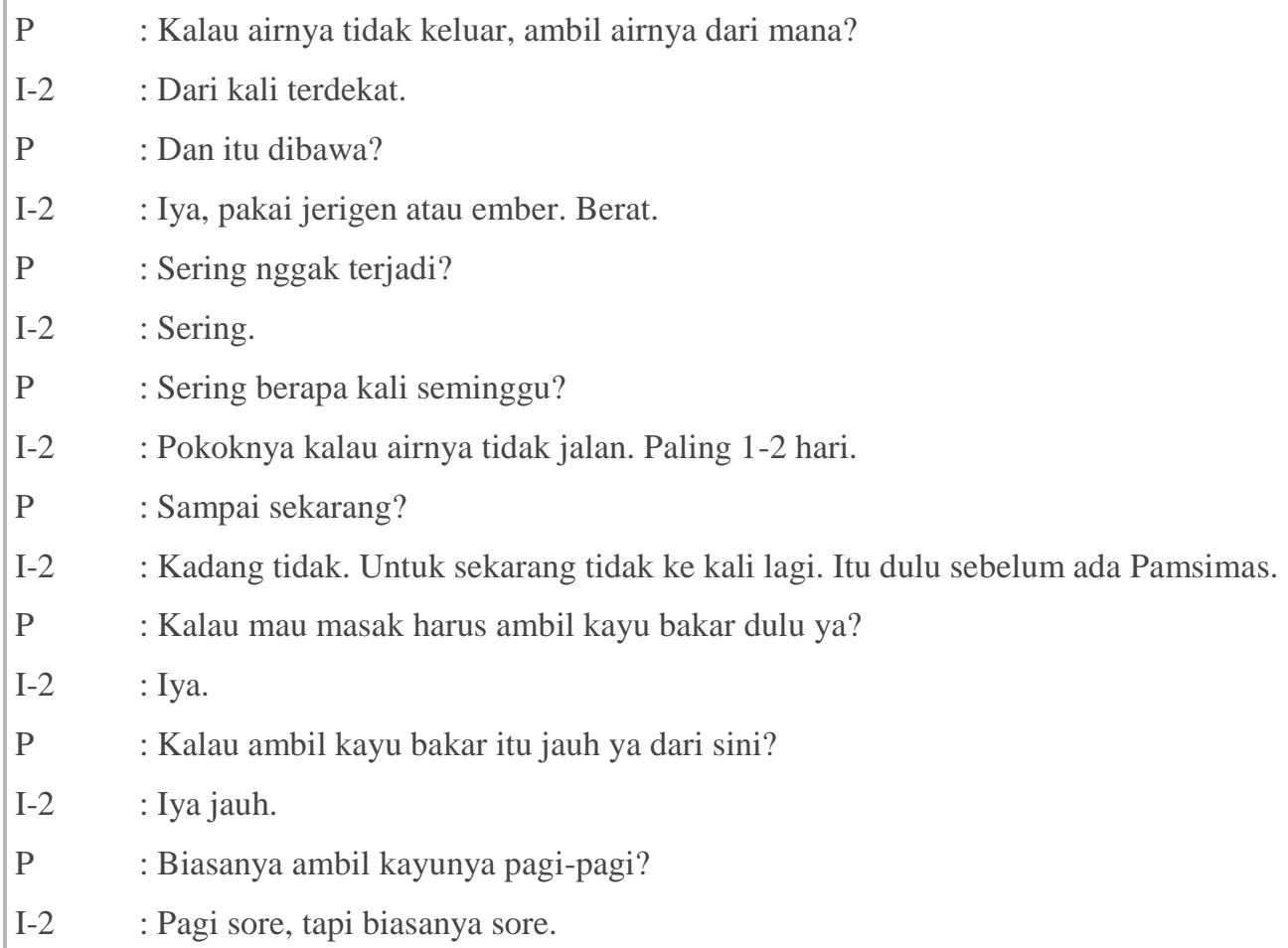

\begin{tabular}{|l|l|}
\hline Nama & Ibu Rita \\
\hline Umur & 34 \\
\hline Jenis Kelamin & Perempuan \\
\hline Pekerjaan & Ibu Rumah Tangga \\
\hline
\end{tabular}

\section{Hasil Wawancara}

P : MIsalkan diletakkannya di satu tempat, kalau keran kan ada di rumah-rumah, kalau ini alatnya di satu tempat, berarti ibu harus kesana, itu nggak masalah?

I-3 : Bisa.

P : Nggak apa-apa, atau merepotkan?

I-3 : Jaraknya?

P : Misalkan satu dusun satu begitu.

I-3 : Ya kalau satu dusun satu bisa. Tapi kalau misalkan ditempatkan di satu tempat, seperti di balai desa begitu, jauh. Mesti butuh ojek lagi. 


\section{Informan 4}

\section{Identitas Informan}

\begin{tabular}{|l|l|}
\hline Nama & Ibu Merina \\
\hline Umur & 40 \\
\hline Jenis Kelamin & Perempuan \\
\hline Pekerjaan & Ibu Rumah Tangga \\
\hline
\end{tabular}

\section{Hasil Wawancara}

P : Bagaimana metode Ibu untuk mengolah air?

I-4 : Airnya disaring dulu pakai kain, sekali. Dibiarkan mengendap dulu, lalu disaring lagi, begitu sampai tiga kali. Dimasak lagi, mesti duduk di tungku dengan asap-asap.

$\mathrm{P} \quad$ : Masak di tungku pakai apa Bu?

I-4 : Pakai kayu api.

$\mathrm{P} \quad$ : Kayu apinya dapat dari mana?

I-4 : Ambil dari hutan, jalan 3 kilo kesana. Biasanya naik ojek lagi.

P : Kalau naik ojek berapa?

I-4 : Biasa 2 ribu, sampai 4 ribu bolak balik.

\section{Informan 5}

\section{Identitas Informan}

\begin{tabular}{|c|c|}
\hline Nama & Bapak Freddy \\
\hline Umur & 48 \\
\hline Jenis Kelamin & Laki-laki \\
\hline Pekerjaan & Petani \\
\hline \multicolumn{2}{|c|}{ Hasil Wawancara } \\
\hline \multicolumn{2}{|r|}{$\begin{array}{l}\text { : Menurut Bapak, bagaimana kalau ada sarana yang dapat langsung menyediakan air } \\
\text { minum langsung tanpa Bapak perlu menyaring dan memasak seperti sekarang? }\end{array}$} \\
\hline : Mens & : Mensyukuri kalau ada. \\
\hline : Sang & : Sangat membantu ya? Daripada harus repot2 masak lagi. \\
\hline : Iya & ena harus pakai kayu api. \\
\hline
\end{tabular}

\section{Informan 6}




\begin{tabular}{|c|c|}
\hline \multicolumn{2}{|c|}{ Identitas Informan } \\
\hline Nama & Ibu Esther \\
\hline Umur & 35 \\
\hline Jenis Kelamin & Perempuan \\
\hline Pekerjaan & Ibu Rumah Tangga \\
\hline \multicolumn{2}{|c|}{ Hasil Wawancara } \\
\hline \multicolumn{2}{|r|}{ : Apakah kalau misalkan ada sarana seperti itu membantu? Air bersih layak minum? } \\
\hline : Kala & : Kalau ada Ibu kami terima. Karena disini tidak ada maka kami pakai apa adanya. \\
\hline \multirow[t]{5}{*}{$\mathrm{P}$} & : Nah kalau begini. Kalau misalkan sarana seperti pipa ini, itu kan harus bayar karena \\
\hline & \multirow{3}{*}{$\begin{array}{l}\text { mereka perlu perawatan, karena itu juga perlu dirawat. Sama seperti ini, ada biaya perawatan yang perlu } \\
\text { dikeluarkan untuk tetap merawat fasilitas ini dengan baik. Nah, kalau misalkan ada biaya yang perlu } \\
\text { dikeluarkan sekitar 1000-2000 per galon, tapi layak minum langsung, kira-kira menurut bapak ibu }\end{array}$} \\
\hline & \\
\hline & \\
\hline & sekalian bisa terima dengan baik atau tidak? \\
\hline \multirow[t]{3}{*}{ I-6 } & \multirow{3}{*}{$\begin{array}{l}\text { Kalau ada biaya yang perlu dikeluarkan tapi itu bermanfaat. Kalau melebihi target } \\
\text { setiap rumah tangga maka kami tidak mampu. Karena kebutuhan kami disini sangat minim. Pen } \\
\text { kami sangat minim. Untuk cari uang saja setengah mati. Desa Oesusu ini orang miskin semua. }\end{array}$} \\
\hline & \\
\hline & \\
\hline \multicolumn{2}{|r|}{ : Begini, dengan adanya fasilitas seperti ini, diharapkan biaya-biaya yang diperlukan } \\
\hline \multicolumn{2}{|r|}{ untuk ke rumah sakit, untuk menanggulangi kalau karena minum air yang kurang bersih, atau karena } \\
\hline \multicolumn{2}{|r|}{ mikul kayu api yang jauh dari sana, itu kan jadi biayanya berkurang. Jadi diharapkan biaya itu bisa } \\
\hline \multicolumn{2}{|r|}{ dialihkan lebih untuk kebutuhan sehari-hari, seperti untuk minum begitu. Jadi kalau misalkan nanti ada } \\
\hline & alatnya mungkin bisa dicoba dulu biar ibu bisa merasakan, seperti itu. \\
\hline
\end{tabular}

\section{Wawancara 2: Kepala Desa Oesusu}

Tanggal Wawancara : 21 September 2017

Tempat / Waktu : Desa Oesusus, NTT / Pukul 16.35 WITA

Jenis Informan : Tokoh Masyarakat

\section{Informan 7}

\section{Identitas Informan}

\begin{tabular}{|l|l|}
\hline Nama & Pak Bernard Bait \\
\hline Umur & 53 \\
\hline Jenis Kelamin & Laki-laki \\
\hline
\end{tabular}




\section{\begin{tabular}{|l|l}
\hline Pekerjaan & Kepala Desa
\end{tabular}}

\section{Hasil Wawancara}

$\mathrm{P} \quad$ : Bagaimana perihal masalah air di Desa Oesusu?

I-7 : Puji Tuhan, sejak tahun lalu warga desa telah lebih mudah mendapatkan air. Sekarang air telah dialirkan

ke

masing-masing rumah di Dusun Bawah.

P : Puji Tuhan, berarti warga telah lebih mudah mendapatkan air ya, untuk sekarang kendalanya apa saja ya Pak?

I-7 : Saat ini kami baru bisa mengalirkan air untuk Dusun Bawah saja, namun Dusun Air masih kesulitan air. Berbeda dengan Dusun Bawah yang menggunakan gravitasi untuk mengalirkan air, dibutuhkan pompa untuk dapat mengalirkan air ke Dusun Atas dan kami tidak punya pompa itu.

P : Oooh, berarti warga Dusun Atas tidak mendapatkan air sama sekali Pak?

I-7 : Warga Dusun Atas tidak mendapatkan air dengan mudah seperti warga Dusun Bawah, mereka perlu jalan

ke mata air yang jauh untuk mendapatkan air.

P : : Apakah ada masalah lainnya? Bagaimana dengan kualitas air di Desa Oesusu Pak?

I-7 : Untuk Desa Bawah air telah dialirkan dengan baik dan tidak ada masalah, namun memang untuk kualitas air kurang baik karena air di sini mengandung kapur yang sangat tinggi. Kami mengajarkan warga untuk memasak dan menyaring air sebelum diminum.

P : : Apakah air yang dimasak dan disaring sudah cukup aman bagi kesehatan warga?

I-7 : Belum, tapi itu lebih baik daripada air langsung diminum. Warga di sini memiliki ginjal yang kuat jadi tidak gampang sakit, bahkan warga Dusun Atas terbiasa untuk langsung meminum air tanpa dimasak dan disaring.

P : Berarti kualitas air permasalahan yang sampe sekarang belum terselesaikan ya?

I-7 : Iya saat ini belum ada teknologi untuk itu.

P : Saat ini kami sedang berusaha mengembangkan teknologi untuk dapat menyaring air tersebut menjadi air yang aman untuk diminum. Harapan kami, teknologi ini dapat membantu menyelesaikan masalah di Desa Oesusu dan desa-desa lainnya.

I-7 : Wah itu benar-benar yang kami butuhkan. Baru saja tadi siang kami mengadakan rapat untuk membicarakan ini. Selama yang adik-adik lakukan bertujuan untuk membantu masyarakat, saya akan bersedia untuk membantu.

P : Terima kasih Pak. Untuk saat ini pertanyaan kami sampai sini dulu, jika kami membutuhkan informasi mohon bantuannya ya Pak. 
I-7 : Ya tentu saja, terima kasih juga.

Wawancara 3: Lembaga Swadaya Masyarakat

Tanggal Wawancara : 20 September 2017

Tempat / Waktu : Kantor Cabang Wahana Visi Indonesia, Kota Kupang, NTT

Jenis Informan : : lembaga pembina masyarakat desa

\section{Informan 8}

Identitas Informan

\begin{tabular}{|l|l|}
\hline Nama & Ibu Pritta Damanik \\
\hline Umur & 28 \\
\hline Jenis Kelamin & Perempuan \\
\hline Pendidikan Formal & S1 \\
\hline Pekerjaan & Supervisi Lapangan Wahana Visi Indonesia \\
\hline
\end{tabular}

Hasil Wawancara

P : Berdasarkan keadaan lapangan apakah sudah banyak fasilitas yang diimplementasikan untuk mengatasi permasalahan air di desa Oesusu?

I-8 : Kalau di desa Oesusu kebetulan di beberapa dusun sudah dibangun sistem pipa untuk menyediakan air bersih ke rumah-rumah warga. Tapi khusus bagian dusun yang diatas mereka masih belum ada sistem pipa.

Mereka masih mengambil air dari satu sumber air yang dulu pernah dibangun.

$\mathrm{P} \quad$ : fasilitas itu sudah menyelesaikan masalah yang ada bu di desa Oesusu?

I-8 : kalo menyelesaikan masalah si belum ya, karena air disana mengandung banyak kapur, jadi kualitas air yang diperoleh masyarakat sangat tidak layak

$\mathrm{P} \quad$ : melihat kondisi tersebut apakah sudah ada pihak-pihak pengembang yang mencoba menyelesaikan ?

I-8 : bisa dibilang pihak-pihak pengembang agak sembarangan membuat fasilitas karena kalau untuk melayani semua masyarakat investasinya besar dan tidak mereka kadang-kadang tidak tau teknis yang benar, ujungujungnya fasilitas rusak

P : kalau boleh tau mengapa pengembang sering melakukan hal itu dan kenapa fasilitas sering rusak?

I-8 : masalah klasik, investasi tinggi jadinya ga sesuai standar spek. Kedua karena semata-mata hibah jadi tidak ada pengembang yang memikirkan keberlangsungan fasilitas. Seringkali juga masyarakat tidak dilibatkan, jadi masyarakat ga ada rasa memiliki dan karena mereka mindsetnya gratis jadi kalau rusak ya tinggal tunggu dikasih 
baru.

$\mathrm{P} \quad$ : kalau WVI sendiri bagaimana melihat masalah ini ?

I-8 : kita selalu fokus orientasinya ke masyarakat jadi kita percaya masyarakat perlu dikembangkan dan diedukasi untuk pemeliharaan fasilitas. Contoh perlu ada edukasi secara kegunaan fasilitas untuk mereka, cara merawat fasilitas dan juga pada saat pembangunan perlu dilibatkan supaya tercipta rasa kepemilikan. Terus perlu ada iuran karena masyarakat jangan dibiasakan dikasih gratis, jadi ga tanggung jawab. Biasa juga harus ada program pengembangan masyarakat dan program membangun relasi supaya kita dan masyarakat ga asing n bekerja sama nya enak.

$\mathrm{P}$ : Bedanya pengembangan masyarakat dengan membangun relasi seperti apa?

I-8 : kalau pengembangan masyarakat biasanya harus ditentukan objektifnya dulu, jadi ada tolak ukur dari baseline ke target, contoh misalnya tingkat masyarakat yang tau bedanya air yang bagus untuk diminum dan tidak, nah programnya harus inline sama objektif yang ditargetkan. Kalau relasi lebih ke acara-acara kebersamaan dan melibatkan masyarakat dalam sebuah program yang dikerjakan bersama-sama.

$\mathrm{P}$ : apakah dengan tahapan itu bisa dijamin akan awet?

I-8 : ya secara teknis juga harus bagus, jadi pengembang juga harus membangun dengan baik dan jangan canggihcanggih, supaya masyarakat juga paham. Kalo dari sisi masyarakat, metode yang tadi saya jabarkan sudah cukup terbukti bisa mendukung keberlangsungan, asalkan didesain dengan baik dan bertahap. Biasanya 1-2 tahun prosesnya.

$\mathrm{P} \quad$ : kalau WVI sendiri mengapa tidak membangun fasilitas sendiri?

I-8 : kami kan lembaga masyarakat, jadi lebih spesialisasi di pengembangan masyarakat, dan kita minim di ilmu teknis

$\mathrm{P}$ : kalau seandainya ada bentuk kerjasama antara WVI dengan pengembang teknis apakah mungkin ?

I-8 : sangat memungkinkan, selama ini kita seperti itu

$\mathrm{P}$ : wah terimakasih ya bu

I-8 : sama-sama

\section{Wawancara 4: Teknologi Water Treatment}

Tanggal Wawancara : 5 Oktober 2017

Tempat / Waktu : Institut Teknik Bandung, Bandung / Pukul 13.20 WIB

Jenis Informan : : Pakar

Informan 9

Identitas Informan 
Vol.01, No. 2, 2018

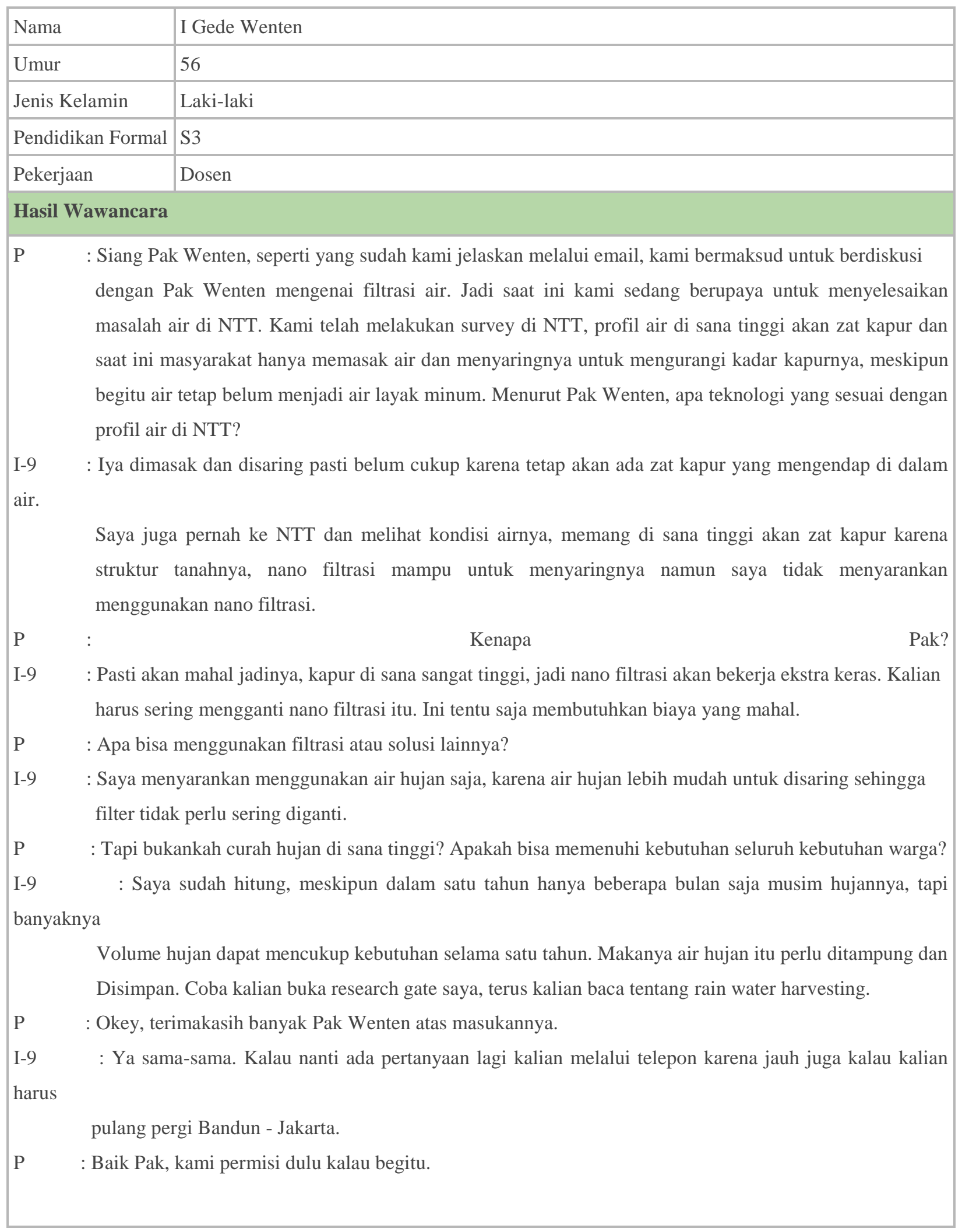




\section{Wawancara 5: Supplier Teknologi Water Treatment}

Tanggal Wawancara : 2 November 2017

Tempat / Waktu : Starbucks Maxxbox Karawaci / 17.30 WIB

Jenis Informan : praktisi

\section{Informan 10}

\section{Identitas Informan}

\begin{tabular}{|l|l|}
\hline Nama & Bapak Heri Koesyamin \\
\hline Umur & 31 \\
\hline Jenis Kelamin & Pria \\
\hline Pendidikan Formal & S1 \\
\hline Pekerjaan & Owner Perusahaan water treatment facilities \\
\hline
\end{tabular}

\section{Hasil Wawancara}

P : Selamat siang Pak Heri

I-10 : Siang, salam kenal

P : Kami kebetulan sedang ada rencana proyek untuk membuat fasilitas pengolahan air menjadi air layak minum di daerah Kupang, kami butuh mitra untuk pengadaan barang dan desain fasilitas yang cocok. Menurut bapak bagaimana?

I-10 : profil air nya seperti apa dan di perkotaan atau perdesaan?

$\mathrm{P}$ : profil airnya kebetulan banyak kandungan kapurnya dan dari sumber air permukaan. Untuk lokasi nya di desa pak

I-10 : air kapur agak sulit, harus dua tahapan, pertama harus gunain filter terus baru di treatment lagi airnya supaya jadi air layak minum, kita ada komponen-kompnonen itu, terus penampunganya perlu dua jenis, satu fibre tank untuk menampungan air di tahap awal, terus stainless steel tank buat nampung air layak minum nya. Kalau lokasi di desa, jalanya besar?

$\mathrm{P}$ : jalan nya lumayan besar $\mathrm{n}$ bagus pak, cuma mungkin yang harus ditanyakan lagi dari drop zone ke desanya bagaimana, kita akan coba kordinasi dengan pihak desa. Untuk komponen-komponen nya cepet rusak ga pak kalau air kapur?

I-10 : kalau air kapur yang harus rutin itu filternya harus diganti 2 bulan sekali dan ada maintenance bulanan buat sistem water treatment nya. Cuman tidak terlalu sulit karena sistem treatment airnya pakai reverse osmosis aja sudah cukup. 
$\mathrm{P}$ : untuk masalah logistic dan pengadaan barang apakah bapak bisa urus semua?

I-10 : bisa kok, nanti kita juga akan sesuaikan dengan gambar desain serta luas fasilitas yang dibutuhkan, jadi harus ada diskusi lanjutan, kalau bisa bawa sampel airnya juga untuk desain water treatment nya.

P: oke pak kita akan proses itu

I-10 : iya itu saja, pengadaan barang bisa kita urus dan teknisi dari kami juga siap bantu untuk implementasi

P: wah terima kasih pak

I-10 : sama-sama

\section{Wawancara 6: Water and Sanitation Program of the World Bank}

Tanggal Wawancara : 31 Mei 2018

Tempat / Waktu : Cilandak Town Square, Jakarta Selatan / Pukul 12.30 WIB

Jenis Informan : Pakar

\section{Informan 11}

\section{Identitas Informan}

\begin{tabular}{l|l}
\hline Nama & Ari Kamasan \\
\hline Umur & - \\
\hline Jenis Kelamin & Laki-laki \\
\hline Pendidikan Formal & S2 \\
\hline Pekerjaan & Behavior Change and Market Development Specialist
\end{tabular}

\section{Hasil Wawancara}

P : Selamat siang Pak Ari terimakasih sudah meluangkan waktu untuk bertemu dengan kami

I-11 : Ya sama-sama. Jadi apa yang bisa saya bantu?

P : Jadi kami sedang membuat Business Plan untuk syarat kelulusan kita tapi kita juga berharap agar bisnis ini bisa benar-benar dijalankan. Dalam BP kami, kami akan menyelesaikan masalah kurangnya akses air layak Minum di Desa Oesusu, Kupang, NTT. Kami membuat sistem dimana kami menggunakan teknologi untuk filtrasi air dan mekanisme bisnis keberlangsungan proyek ini. Namun saat ini kami membutuhkan informasi Pak Ari Kamasan yang telah lebih dulu bergerak di bidang ini dan apakah ada rekomendasi perusahaan CSR yang bisa mendanai proyek ini.

I-11 : Bisa saya liat skemanya?

P : Pasti Pak, silahkan.

I-11 : Jadi kalian akan melakukan community development juga ya.

$\mathrm{P} \quad$ : Iya, community development adalah cara kita untuk berinteraksi dan melakukan edukasi untuk masyarakat.

Dalam hal ini kami akan bekerja sama dengan NGO setempat.

I-11 : Apa nama NGO nya? 


\section{P : Wahana Visi Indonesia}

I-11 : Hmm, fasilitas ini tempat kalian melakukan filtrasi air ya?

P : Iya Pak

I-11 : Nantinya fasilitas akan jadi punya siapa?

P : Fasilitas akan menjadi punya kita Pak atau perusahaan CSR.

I-11 : Ooh ya ya. Memang hingga saat ini permasalah akses air layak minum di Indonesia masih belum terselesaikan. Saya suka dengan sistem yang kalian buat, mekanisme memang harus digunakan karena selama

Ini program yang ada tidak pernah berkelanjutan, tapi perlu kalian ketahui kalo sumber air itu tidak boleh dikuasai oleh swasta. Hal inilah yang selama ini juga menjadi kendala kami.

$\mathrm{P} \quad$ : Ohh begitu ya

I-11 : Iya, tapi jangan patah semangat ya. Saya pribadi suka dengan BP kalian dan pasti banyak juga orang lainnya

yang tertarik, hanya memang menurut saya perlu ada yg sedikit diubah di penggunaan sumber airnya.

Ngomong-ngomong kenapa kalian memilih BP ini?

$\mathrm{P} \quad$ : Hmm, sebenernya tidak ada alasan khusus. Kami hanya melihat ada masalah dalam hal ini dan karena kami semua tertarik dengan hal-hal yang bersifat sosial, kenapa tidak kami membuat bisnis dengan impact sosial Secara langsung.

I-11 : Dan kenapa memilih di daerah Kupang?

$\mathrm{P} \quad$ : Karena kami memiliki kenalan di WVI Kupang dan itu mempermudah kami dalam melakukan market riset operasional di sana.

I-11 : Oooh, bagus-bagus. Sekarang ini saya tidak bisa lama-lama mohon maaf karena harus ada meeting lagi. Tetap

Semangat ya. Kalian bisa kontek saya kapanpun pasti saya bantu. Kalau mau ketemu lagi, paling saya baru bisa setelah lebaran ya.

P : Baik Pak Ari, terima kasih banyak sudah mau datang ke sini.

I-11 : Iya sama-sama. Oiya nanti saya akan kirim file-file yang bisa kalian baca untuk melihat lebih dalam mengenai

issue ini. Nanti saya minta emailnya ya.

P : Baik Pak Ari, terima kasih.

\section{Wawancara 7: Perusahaan Penyelenggara CSR}

Tanggal Wawancara : 12 November 2017

Tempat / Waktu : Cilandak Town Square

Jenis Informan : praktisi CSR

\section{Informan 12}

\section{Identitas Informan}

\begin{tabular}{|l|l|}
\hline Nama & Salman Bachtiar \\
\hline Umur & 43 \\
\hline
\end{tabular}




\begin{tabular}{|l|l|}
\hline Jenis Kelamin & Pria \\
\hline Pendidikan Formal & S2 \\
\hline Pekerjaan & Advisor CSR Corporate \\
\hline
\end{tabular}

\section{Hasil Wawancara}

P : Selamat siang Pak Salman, terima kasih atas waktu bapak

I-12 : Iya sama-sama

P : kebetulan kami ingin mendalami tentang masalah program csr pada saat ini dan mengetahui dari pandangan bapak untuk membuat sebuah program csr yang baik dan menitik beratkan pada aspek keberlangsungan.

I-12 : ohh oke, intinya pada saat membuat sebuah program csr, harus riset dan paham betul kebutuhan perusahaan csr nya apa, karena itu yang jadi daya tarik mereka. Kedua masalahnya apa dan sesuai tidak dengan kebutuhan perusahaan.

$\mathrm{P}$ : kalau untuk keberlangsungan nya bagaimana pak ? Kebanyakan program sering tidak berlangsung lama karena skema hibah, apakah betul ?

I-12 : benar sekali, kebanyakan dengan skema hibah itu tidak ada perputaran uang dan pendampingan, alhasil program tidak akan berlangsung lama. Harus ada skema model bisnis yang melibatkan beberapa stakeholder. Tidak bisa diborong sendiri, harus ada ekosistem nya.

P : skema model bisnis dan ekosistem yang dimaksud seperti apa pak?

I-12 : begini, sebagai contoh, saya mengembangkan program csr untuk petani kopi. Saya bekerja sama dengan perusahaan $\mathrm{x}$ untuk mengelola dana csr mereka untuk pengembangan fasilitas pengolahan biji kopi dan edukasi petani kopi. Untuk edukasinya saya mencari partner ngo setempat untuk membantu. Lalu saya dengan bumdes bekerja sama untuk mengelola hasil biji kopi petani untuk diproses dan dijual ke pembeli. Uangnya akan diterapkan bagi hasil untuk bumdes dan saya. Lalu saya melibatkan perusahaan lain untuk mendanai penambahan pohon kopi dengan menawarkan hitungan jejak karbon untuk setiap pohon yang ditanam sebagai program csr mereka untuk mengurangi produksi jejak karbon. Jadi satu program tapi stakeholdernya banyak dan menghasilkan perputaran uang. Itu baru bisa berlangsung lama dan dampaknya besar dan terukur.

P : ohh begitu pak, terus untuk kerjasama nya apakah mudah ? Hal yang perlu diperhatikan apa saja ?

I-12 : mudah-mudah susah, kalian harus ada lembaga masyarakat lokal disana karena lewat mereka penetrasi ke bumdes gampang, kedua kalian harus bisa mengemas program kalian yang bisa melibatkan banyak pihak yang sesuai dengan keahlian masing-masing pihak.

$\mathrm{P}$ : kalau dari sisi perusahaan csr nya apakah ada yang perlu diperhatikan lagi pak ?

I-12 : kuncinya adalah apa yang kalian bisa tawarkan untuk keuntungan jangka panjang mereka dan keberlangsungan nya. Dua itu terjawab, mereka akan memberikan csr mereka. Jadi disini riset ke calon perusahaan perlu diperhatikan

P : pak apakah swasta perlu mengelola atau mendampingi bumdes dalam mengelola ? 
I-12 : sangat perlu, kalau fasilitas langsung diberikan ke desa dan langsung membentuk koperasi, seringkali ditengah jalan akan gagal karena mereka tidak memiliki kemampuan yang baik dalam manajemen, jadi harus kerjasama pengelolahan antar swasta dengan bumdes, dan sistem model bisnis

$\mathrm{P} \quad$ : oke pak paham

I-12 : mungkin itu dari saya soal program csr, kalau ada pertanyaan lagi email saja

$\mathrm{P} \quad$ : terima kasih pak sekali lagi atas waktunya

I-12 : sama-sama 